\title{
ALIGNMENT STRATEGIC IN PROJECT-BASED BUSINESSES: A REVIEW OF THE LITERATURE
}

\author{
Jéssica Vivianne da Cunha Silva de Brito ${ }^{1}$ (iD Josué Vitor de Medeiros Júnior ${ }^{2}$
}

\author{
${ }^{1}$ M.Sc in Administration, Federal University of Rio Grande do Norte - UFRN. Natal, Rio Grande do Norte - Brazil. \\ brito.jessicacunha@gmail.com \\ ${ }^{2}$ PhD in Administration, Federal University of Rio Grande do Norte - UFRN. Natal, Rio Grande do Norte - Brazil. \\ josuevitor16@gmail.com
}

\begin{abstract}
Objective: This literature review sought to understand the theoreticalempirical connections of strategic alignment in project-based businesses Methodology: We carried out a systematic review with searches in scientific databases (Web of Science and Scopus) and application of technical snowballing with the intention of finding the most relevant works on the topic. The strings adopted were based on the keywords: project-based businesses and strategy. Filters related to the research area, the document types and the language were applied. The selected articles were analyzed following the steps: removal of duplicates, reading of titles, abstracts and quality assessment. After these steps, 20 papers were analyzed in a descriptive and exploratory way using VOSviewer, Biblioshiny and MS Excel software.

Originality: The paper filled a gap concerning strategic alignment in the context of project-based business, which is an emerging concept that is little debated in the literature.

Main results: The results showed a mutual influence between strategy alignment and project management. It was found that the first helps organizations to focus on correct projects, while project management helps achieves their strategic objectives. Four research focuses related to the strategic alignment in the PBB were also published in the literature: project management and organizational strategy; interaction between actors in the formation of strategies; program, portfolio and governance management project management office and organizational design.

Contributions: The contribution consists of presenting a set of propositions that systematize the findings of the papers and elucidate ways for the formation of a research agenda.
\end{abstract}

Keyword: Project-based business. Strategic alignment. Project management. Systematized literature review.

\section{ALINHAMENTO ESTRATÉGICO EM NEGÓCIOS BASEADOS EM PROJETOS: UMA REVISÃO DA LITERATURA}

\section{Resumo}

Objetivo: Esta revisão da literatura buscou esclarecer como o alinhamento estratégico ocorre em Negócios Baseados em Projetos (NBPs).

Metodologia: Foi realizada uma revisão sistematizada, com buscas em bases de dados científicas (Web of Science e Scopus) e aplicação da técnica snowballing para identificar os trabalhos mais relevantes sobre o tema. Os strings adotados foram elaborados a partir das palavras-chave: negócios baseados em projetos e estratégia. Foram aplicados filtros referentes à área de pesquisa, ao tipo dos arquivos e ao idioma. Os trabalhos obtidos passaram pelas estratégias de seleção: remoção dos duplicados, leitura dos títulos, dos resumos e avaliação da qualidade. Após essas etapas, 20 artigos foram analisados de forma descritiva e exploratória por meio do uso dos softwares VOSviewer, Biblioshiny e MS Excel.

Originalidade: $\mathrm{O}$ trabalho preencheu uma lacuna no tocante ao alinhamento estratégico no contexto dos NBPs, o qual é um conceito emergente pouco debatido na literatura.

Resultados: Os resultados demonstraram uma influência mútua entre o alinhamento da estratégia e a gestão de projetos. Identificou-se que o primeiro ajuda as organizações a concentrarem seus esforços nos projetos oportunos, enquanto o segundo as auxilia a atingirem suas metas estratégicas. Também foram identificados quatro focos de pesquisas relacionados ao alinhamento estratégico em NBP: gestão de projetos e estratégia organizacional; interação entre atores na formação de estratégias; gestão de programas, portfólio e governança; escritório de gerenciamento de projetos e design organizacional.

Contribuições: A contribuição consiste em apresentar um conjunto de proposições que sistematizam os achados e elucidam caminhos para a formação de uma agenda de pesquisa.

Palavras-chave: Negócio baseado em projetos. Alinhamento estratégico. Gestão de projetos. Revisão sistematizada da literatura.

\section{ALINEACIÓN ESTRATÉGICA EN NEGOCIOS BASADOS EN PROYECTOS: REVISIÓN DE LA LITERATURA}

\section{Resumen}

Objetivo: Esta revisión de la literatura buscó comprender las conexiones teórico-empíricas de la alineación estratégica en negocios basados en proyectos (NBP).

Metodología: Para ello se realiza una revisión sistemática, con búsquedas en bases de datos científicas (Web of Science y Scopus) y aplicación de la técnica de bola de nieve para identificar los trabajos más relevantes sobre el tema. Las cadenas adoptadas en las búsquedas se elaboraron a partir de las palabras clave: negocios basados en proyectos, organizaciones basadas en proyectos y estrategia. Se aplicaron filtros en cuanto al área de investigación, el tipo de archivos y el idioma. Los trabajos obtenidos pasaron inicialmente por las estrategias de selección: eliminación de duplicados, lectura de títulos, resúmenes y evaluación de la calidad. Tras estos pasos, se analizaron 20 artículos de forma descriptiva y exploratoria utilizando el software VOSviewer, Biblioshiny y MS Excel.

Originalidad: el artículo llenó un vacío en cuanto a la alineación estratégica en el contexto de negocios basados en proyectos, un concepto emergente y poco discutido en la literatura.

Resultados principales: Los resultados demuestran una influencia mutua entre la alineación estratégica y la gestión de proyectos. Se encontró que el primero ayuda a las organizaciones a enfocar sus esfuerzos en proyectos oportunos, mientras que el segundo les ayuda a alcanzar sus metas estratégicas. También se identificaron en la literatura cuatro enfoques de investigación relacionados con la alineación estratégica en NBP: gestión de proyectos y estrategia organizacional; interacción entre actores en la formación de estrategias; gestión de programas, carteras y gobernanza; oficina de gestión de proyectos y diseño organizacional

Contribución: La contribución del trabajo consiste en presentar un conjunto de propuestas que sistematizan los hallazgos de los artículos y dilucidan formas para la formación de una agenda de investigación.

Palabras clave: Negocio basado en proyectos. Alineación estratégica. Gestión de proyectos Revisión sistemática de la literatura.

\section{Cite as / Como citar}

Brito, J. V. da C. S., \& Medeiros, J. V., Jr. (2021). Alignment strategic in project-based businesses: a review of the literature. Iberoamerican Journal of Strategic Management (IJSM), 20, 1-25, e17902. https://doi.org/10.5585/riae.v20i1.17902. 


\section{Introduction}

It is possible to verify a transition of project management role, previously seen as an undertaking in the delivery of specific results, to be considered as an important resource in the realization of organizational strategies (Dietrich \& Lehtonen, 2005). As a result of this, the literature in project management is increasingly presenting studies that cover the context of the strategy's implementation (Kwak \& Anbari, 2009).

This way, project management becomes an approach of great relevance for changes in business and the adoption of project management techniques has been recognized as relevant to the achievement of strategic organizational objectives (Morris \& Jamieson, 2005; Srivannaboon \& Milosevic, 2006).

Moreover, it is understood that further and more specific investigation is still needed to explore how projects in general contribute to the strategy (Young \& Grant, 2015). The knowledge in how to align both topics can help organizations to focus on adequate projects and reach strategic goals more effectively (Ansari, Shakeri \& Raddadi, 2015).

In the context of project-based businesses (PBB), aspects related to this alignment can be even cloudier, given the complexity of such organizational model and the shortage in studies that go in detail over the PBB's. Specifically, the literature presents several challenges such as the selection and execution of projects in project-based organizations (Ansari et al., 2015).

In these organizations the alignment between project and strategy is essential, because considering that a PBB is an organizational structure in which the strategy is formulated and executed in the means of projects (Sousa, 2017), it is understood that the alignment seeks to deal with both the aspects inherent to the strategy implementation, as well as with the execution of projects.

An essential aspect for the success of this alignment is to translate the strategy into projects, allowing organizations to obtain effective results in organizational alignment, creation of synergies, communication, integration between senior management other functional units, standardization of efforts and indicators, monitoring of performance and the effective implementation of the strategy (Schwarz, Amiden \& Pinho, 2005).

Considering the presented conjuncture, the question that guided this research was: how do the theoretical-empirical connections of strategic alignment in project-based businesses occur? Thus, it was sought through this paper to understand the theoretical-empirical connections of strategic alignment in project-based businesses. To this end, a systematized review of literature (SRL) was executed based on the process recommended by Costa and Zoltowski (2014), also being considered one of the orientations from Ferrari, Oliveira, Siqueira \& Silva (2017) and adopted the protocol for paper quality evaluation suggested by Dyba and Dingsoyr (2008).

This research enriched the literature about project management, especially concerning understanding the relationship between organizational strategy and projects in the project-based business area. This approach is innovative because until then there was no study in the bibliography 
that specifically addressed the context of this business model. The papers present in the literature until then were about project-based organizations, such is a concept, which, despite the apparent similarity, is distinguished in essence from that of PBB, as explained in the section on theoretical framework.

The results obtained showed the existence of a mutual influence between strategy alignment and project management. While alignment allows organizations to dedicate themselves to the right projects, project management enhances the chance of strategic objectives achieved. Its main contribution consists of presenting a set of propositions that systematize the findings of the articles and elucidate ways for the formation of a research agenda.

The following work presents, beyond this introduction: a section of theoretical background, in which the concepts and definitions used in this research are established; the methodological procedures, that show the form in which the investigation has been conducted; the data analysis from the systematic review, that consists in the description and exploration of the papers obtained in the searches; and at the end, the final considerations, containing findings, limitations and contributions of the study.

\section{Theoretical framework}

It is possible to find in literature a variety of terms and concepts that address the topics studied by this work. This variety not infrequently creates some doubts that make the understanding of the topics harder, mainly in what concerns the meaning of the concepts, in what they overlap and in what they differentiate. For these reasons, it is important that the adopted theoretical constructs are presented, as to mitigate possible interpretative misunderstandings.

The first concept to be adopted is strategy, which is the most appearing concept in scientific papers on the field of administration and business, according to the Web of Science, appearing in 4.322 works over the last 5 years. Literature shows a great number of definitions to this term, at the same time that it highlights a serious issue regarding its implementation on practice. According to data, only $30 \%$ of strategies are implemented and only about $5 \%$ of employees understand it properly (Kenny, 2006; Raps, 2005).

Considering this scenario, one way to address this challenge is to unfold or translate the strategy into projects. This process implies establishing goals, indicators and actions that develop the strategy of an organization inside its functional units and generate information about how those units contribute to the achievement of the organizational strategy (Schwarz et al., 2005). This approach becomes adequate in the context of this research, because it is indicated for cases of organizations that have different units with different goals and actors, what is in accordance with the reality of PBB's. In addition to that, according to Schwarz et al. (2005), the unfolding process of the strategy is useful to understand the organizational singularities and to guarantee synergies different business units. 
In this paper, considering the limited number of studies that directly speak about the concept of the unfolding, especially in the context of the PBB's, the alignment is adopted as a key concept, whose essence presents a similarity with the unfolding. It is understood that the latter implies the "translation" of the strategy in projects, while the first focuses on the projects that are compatible with the strategy.

It is also important to highlight that, in this study, the theoretical approach adopted in relation to strategy is close to the functionalist current, because the questions related to it and its alignment start from an objective point of view, interpreted in a realistic and deterministic way (Burrell \& Morgan, 1987). This paradigm stands out because it believes that when analyzing strategic alignment in the light of project management, it is necessary to have a vision that understands the organization from a functional point of view.

Analyzing the strategic alignment from this perspective, it is understood that it is a mechanism that helps organizations to make adjustments between their strategic interests and the resources available at the organizational level (Ansari et al., 2015). Concerning the theme, the bibliography shows increasing attention on the part of the scholars of the strategy area, however, there is no standardization of the concepts adopted nor a uniform line of approaches on the theme (Ansari et al., 2015; Srivannaboon \& Milosevic, 2006).

Investigating the topics, it is identified there is growing interest to the relationship between strategic alignment and project management (Morris \& Jamieson 2005; Shenhar, Milosevic, Dvir \& Thamhain, 2007; Srivannaboon \& Milosevic, 2006; Aubry et al., 2007; Englund \& Graham, 1999). Observing these findings of the studies, it appears that one of the main challenges imposed on organizations in the alignment process is to find an effective method of translating strategies in projects (Ansari et al., 2015).

About this theme, a variety of concepts emerges to help to establish a relationship between strategy and projects. Examples are portfolio management, program management, project strategy, among others. Analyzing them, it is possible to understand that the literature does not present a standardization of the approaches used by theorists. Because of this, Table 1 shows the definitions of these terms according to the adopted in this study. 
Table 1 - Concepts and definitions verified in this research

\begin{tabular}{|c|c|c|}
\hline Concepts & Definitions & Sources \\
\hline $\begin{array}{l}\text { Strategic } \\
\text { alignment }\end{array}$ & $\begin{array}{l}\text { "Collaborative state where project activities continually support the } \\
\text { achievement of enterprise strategic goals". }\end{array}$ & $\begin{array}{l}\text { Shenhar et al., } \\
\text { 2007, p. } 7 .\end{array}$ \\
\hline $\begin{array}{l}\text { Project } \\
\text { management }\end{array}$ & $\begin{array}{l}\text { "Constitutes the application of knowledge, skills, tools and techniques to } \\
\text { the activities of the project para meet its requirements". }\end{array}$ & PMI, 2017, p. 5. \\
\hline $\begin{array}{c}\text { Program } \\
\text { management }\end{array}$ & $\begin{array}{l}\text { "It's the application of knowledge, skills, tools and techniques to a program } \\
\text { in order to meet its requirements and obtain benefits and control that are } \\
\text { unavailable when managing projects individually". }\end{array}$ & PMI, 2017, p. 9. \\
\hline $\begin{array}{c}\text { Portfolio } \\
\text { management }\end{array}$ & $\begin{array}{l}\text { "The management of portfolios refers to the centralized managing of one } \\
\text { or more portfolios to achieve strategic goals". }\end{array}$ & PMI, 2017, p. 10. \\
\hline Project strategy & $\begin{array}{l}\text { The project's guidelines, methods, and situations for what it aims to do and } \\
\text { how it wants to achieve the best value and utmost competitive advantage. }\end{array}$ & $\begin{array}{l}\text { Shenhar et al., } \\
2007 .\end{array}$ \\
\hline $\begin{array}{c}\text { Project-based } \\
\text { business }\end{array}$ & "Are businesses formulated and executed based on projects". & Sousa, 2017, p.1 \\
\hline $\begin{array}{l}\text { Project-based } \\
\text { organizations } \\
\quad(\mathrm{PBO})\end{array}$ & Are organizations whose businesses are structured, in fact, around projects. & \multirow{3}{*}{ Archibald, 2005.} \\
\hline $\begin{array}{l}\text { Project-oriented } \\
\text { organizations }\end{array}$ & Organizations that trade their products or services based on projects. & \\
\hline $\begin{array}{l}\text { Project-dependent } \\
\text { organizations }\end{array}$ & $\begin{array}{l}\text { Are organizations that depend on projects for the evolution of their main } \\
\text { businesses, but not because they do not have their products or services } \\
\text { based on projects. }\end{array}$ & \\
\hline
\end{tabular}

Source: PMI (2017), Sousa (2017), Shenhar (2007, Archibald (2005).

Another topic focused on this research is the project-based business (PBB). This concept may be the most complex for comprehension, because the lack of standardization of its definition creates a myriad of different approaches. In addition, it is possible to verify both in national and international publications, a limited number of papers that treat specifically about "project-based businesses", which also works in detriment of the concept's complete comprehension.

There are multiple ways found on papers to refer to this kind of organizational model: "projectoriented companies"; "project-based firms"; "project-dependent organizations"; "project business", among others (Anselmo, 2019). According to Archibald (2005), there are differences in the definitions of some of those concepts, which are presented at Table 1. However, it is noticed that in many cases these concepts are applied as synonyms.

For that reason, considering the focus of the present research and analyzing the terms in the literature, it was decided that those will be adopted as synonyms, as is believed that they keep the same essence at their cores. The papers that present uncommon approaches that do not fit known definitions will be analyzed separately.

In the case of this study, it is important to punctuate that the definition of PBB initially adopted was presented by Sousa (2017), that conceptualizes this organizational model as businesses formulated and executed based on projects, meaning businesses that work by projects. The choice for this definition was made because of its simplicity and coverage. The author adds that, in the case of the PBB, "the life cycle of the business is the life cycle of the projects themselves" (Sousa, 2017, p. 1). 
In addition to this definition, the criteria proposed by Huemann \& Stummer (2000) were also adopted to characterize this business model: (1) the organization adopts management by projects as an organizational strategy?; (2) the organization creates temporary undertakings to accomplish complex processes?; (3) the organization has a portfolio with distinct kinds of projects?; (4) the organization applies a new project-based management paradigm?; (5) the organization has an explicit culture of project management?

In conclusion, it is worth identifying in literature the fundamental aspects regarding the idea of alignment and its applications. It's verified that the study on strategy alignment and its relationship with project management was neglected for a long time, until Srivannaboon and Milosevic (2004; 2006) developed a theoretical structure for this relationship and defined alignment as the degree in which the priorities of the project management at an organization are consistent with the priorities of its business strategy. Such relationship will help organizations to concentrate on projects and to fulfill their strategic goals. The issue with establishing such alignment lies in the fact that those goals not always interact with project management activities and their projects, which requires a meticulous control effort (Ansari et al., 2015).

Besides, as observed in literature, this relationship presents an incipient analysis, fact that stimulates the development of this paper analysis, whose methodology (and its application) is presented as the following.

\section{Methodology}

This paper opted for the realization of a literature review due to it comprehension that the method offers a "map of knowledge", which increases the understanding of what has already been scientifically produced over a certain topic (Fisch \& Block, 2018; Frank \& Hatak, 2014). This approach was adopted, to the detriment of the others, as it allows understanding the state of knowledge on a specific topic, creating research agendas, and identifying gaps in the literature (Snyder, 2019).

In this study, it was executed based on the procedure recommended by Costa and Zoltowski (2014), Figure 1, which suggests 8 steps to the conduction of a systematized review. Some of the recommendations made by Ferrari et al. (2017) concerning study identification were also followed, as well as the protocol for paper quality evaluation by Dyba and Dingsoyr (2008). It is believed that those methodological instructions contributed both to minimize researcher bias, as well as increasing the accuracy and the quality of the review. 
Figure 1 - Building process of a systematic review of literature

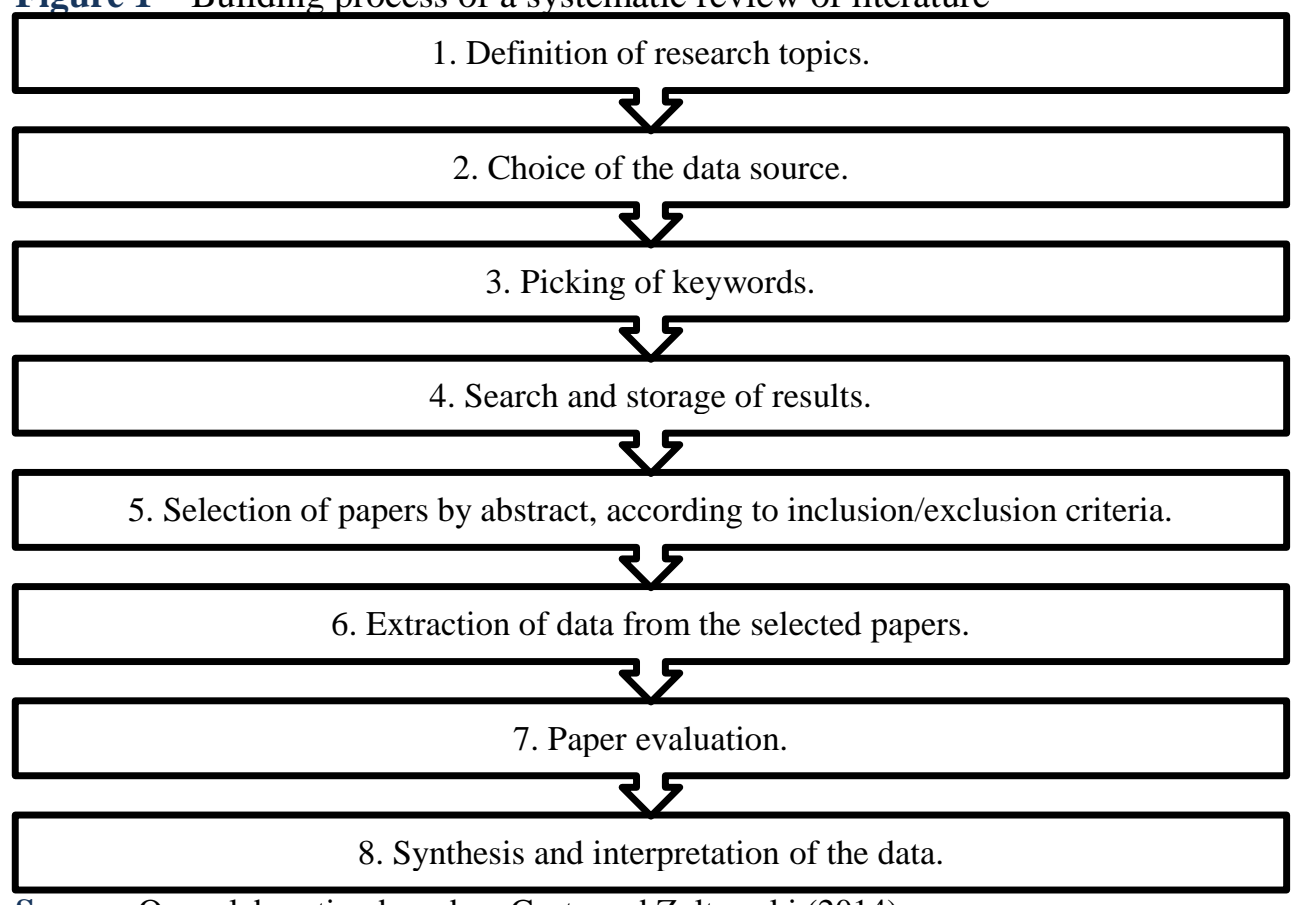

Source: Own elaboration based on Costa and Zoltowski (2014).

It is highlighted that the conducted review was a systematized review, which differs from the systematic review, as it does not encompass all steps and criteria established by the latter. The systematized review is normally made by post-graduate students que seek to do a review in the molds of a systematized review, but lack the means to fulfil all of the required steps, such as the existence of a second researcher to validate the searches, and adequate time to redo them (Grant \& Booth, 2009).

\section{Application of the systematized review of literature}

Following the flux orientations from Costa and Zoltowski (2014), the first step was deciding the question that this research seeks to answer, which was defined as the following: how do the theoretical-empirical connections of strategic alignment in project-based businesses occur? This question was established considering the researcher's need for a clear relationship between the concepts that he wishes to study, in order to obtain a precise and relevant research (Ferrari et al., 2017).

In regard to data sources, Web of Science and Scopus were the main databases used in this investigation. Considering that no individual source of data is capable of returning all relevant papers to a bibliographic review (Ferrari et al., 2017), those databases were selected based on the following criteria: scope; content updates; availability of complete texts; quality of research and results; ease in exporting results; and usability (Dieste, Grimán \& Juristo, 2009).

When defining the search strings, the boolean operators AND e ORs were used. Initially, the keywords utilized were "project-based businesses", "project-based organizations", "strategy" and "strategic". The preliminary search was made as a pilot in order to verify the need for keyword adaptation, as well as inserting new techniques to find relevant studies. 
The research was not restricted by time but limited to the areas of management and business. Besides, two filters were also applied: one related to the kinds of publications, which filtered out any study that was not a paper, and other related to the publication's language, in which only studies in English were selected. This search resulted in 76 papers (Table 2).

Table 2 - Search procedure in the databases

\begin{tabular}{|c|c|c|c|}
\hline \multicolumn{4}{|c|}{$\begin{array}{l}\text { Research question: How do the theoretical-empirical connections of strategic alignm } \\
\text { businesses occur? } \\
\text { Date of research: March 11, } 2020 .\end{array}$} \\
\hline \multirow{2}{*}{ Filters } & \multirow{2}{*}{ Description } & \multicolumn{2}{|c|}{ Results } \\
\hline & & Web of Science & Scopus \\
\hline Search string & $\begin{array}{l}\text { "project-based businesses" OR "project- } \\
\text { based organizations" AND strategy OR } \\
\text { strategic }\end{array}$ & 67 & 100 \\
\hline Research areas & Business and Management & 33 & 57 \\
\hline Document types & Papers & 33 & 43 \\
\hline Language & English & 33 & 43 \\
\hline
\end{tabular}

Sources: Research data (2020).

After the initial search, the obtained results were verified in order to remove duplicities, excluding 19 works. The titles of the works were then read to identify those that seemed to have an alignment with the issue tackled in this research. This step excluded 32 papers in which the title gave no indication that they were related with the investigation`s topic. The papers in which the titles lacked explicit relationship were archived for further analysis, totaling 7.

The next step was reading the abstracts of the papers. This part was conducted to verify the adherence to the research topic, ones where no relationship was found being removed from the sample. Thirteen papers remained after this process, which were then stored according to a categorization procedure based on the following elements: an identifying code, publishing year and author surname and title. It is possible to find the final paper bank at bit.ly/rsl1papers.

At this moment occurred an inversion of the steps proposed by Costa and Zoltowski (2014): first, the paper evaluation was made, followed by the data extraction. This way, the 13 papers that passed through the initial filters were fully read and were subjected to a quality evaluation made based on an adaptation of the evaluation form proposed by Dyba and Dingsoyr (2008). Despite the recommendation that the forms are elaborated specifically for each review (Felizardo, Souza \& Falbo, 2017), it was decided to use of a pre-existing form as some of the topics proposed by the authors are applicable to the papers that make the scope of this investigation. It is important to highlight that during 
the reading process, 3 papers were excluded for being out of this research`s scope, so that only 10 papers remained in the paper bank.

Figure 2 - Protocol for paper selection

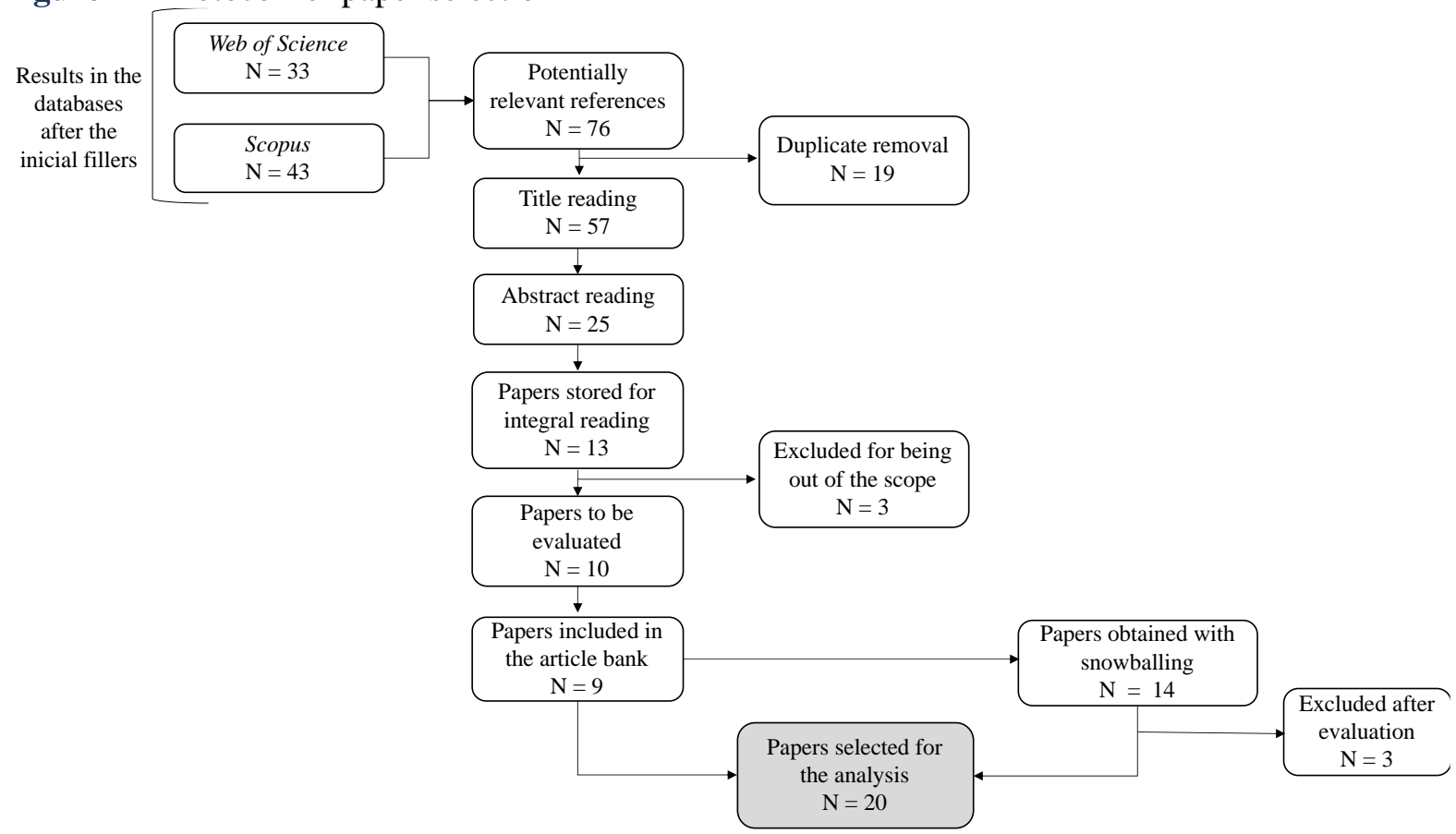

Source: Own elaboration (2020).

The papers were evaluated by giving grades to the analyzed criteria, giving score 1 to the papers that did not attend to the criteria, 3 to those that partially attended and 5 to the ones that adequately attended the criteria. At the end, papers that presented an average score equal or higher than 3 remained in the sample. At this moment, 1 paper was excluded from the sample. Table 3 presents the adopted criteria.

Table 3 - Protocol for paper quality evaluation

\begin{tabular}{|c|c|c|}
\hline \multicolumn{3}{|c|}{ Quality evaluation card } \\
\hline Item & Criteria & Score \\
\hline 1. & This paper is the result of an empiric and/or theoretical research? & \\
\hline 2. & The objectives of the research are made clear? & \\
\hline 3. & The context in which the research was conducted is adequately descripted? & \\
\hline 4. & The research design is appropriate for its objectives? & \\
\hline 5. & Sample selection and/or bibliographical review was adequate to research's objectives? & \\
\hline 6. & The data analysis was rigorous enough? & \\
\hline 7. & The research findings are made clear? & \\
\hline 8. & The study is valuable to practice or literature? & \\
\hline & Avera & \\
\hline
\end{tabular}

Source: Own elaboration based on Dyba and Dingsoyr (2008).

After paper quality evaluation, a total of 9 papers remained, which are presented at Table 4. 
Table 4 - Paper inserted in the database after qualification criteria

\begin{tabular}{|c|l|c|}
\hline Number & \multicolumn{1}{|c|}{ Paper title } & $\begin{array}{c}\text { Average } \\
\text { score }\end{array}$ \\
\hline $\mathbf{1}$ & Framework for Aligning Project Management with Organizational Strategies & 4,25 \\
\hline $\mathbf{2}$ & Doing strategy in project-based organizations: actors and patterns of action & 4,75 \\
\hline $\mathbf{3}$ & Recent developments in project-based organizations & 4 \\
\hline $\mathbf{4}$ & The organizational design of the project-based organization & 4,5 \\
\hline $\mathbf{5}$ & $\begin{array}{l}\text { Benchmarking the strategic roles of the project management } \\
\text { office (PMO) when developing business ecosystems }\end{array}$ & 4,25 \\
\hline $\mathbf{6}$ & $\begin{array}{l}\text { The organization design perspective on the project-based organization: a } \\
\text { structured review }\end{array}$ & 4,25 \\
\hline $\mathbf{7}$ & $\begin{array}{l}\text { An investigation of the influence of organizational design on project portfolio } \\
\text { success, effectiveness and business efficiency for project-based organizations }\end{array}$ & 4,5 \\
\hline $\mathbf{8}$ & $\begin{array}{l}\text { Project-Based Organizing and Strategic Management: A Long-Term Research } \\
\text { Agenda on Temporary Organizational Forms }\end{array}$ & 4 \\
\hline $\mathbf{9}$ & $\begin{array}{l}\text { Institutional Dynamics of Project-Based Creative Organizations: Irving Thalberg } \\
\text { and the Hollywood Studio System }\end{array}$ & 4 \\
\hline
\end{tabular}

Source: Research data (2020).

During the review, papers that scored high enough had their data extracted and disposed on a worksheet. "This procedure helps in the more general visualization of the papers, making it possible to organize and compare them" (Felizardo et al., 2017, p. 65). For the purposes of this research, the extracted data were disposed in forms as shows Table 5.

Table 5 - Card of paper data extraction

\begin{tabular}{|l|l|}
\hline \multicolumn{1}{|c|}{ Item } & Paper: identification (ID) \\
\hline Title & \\
\hline Authors & \\
\hline Year & \\
\hline Citations & \\
\hline Journal or event & \\
\hline Impact factor of the journal & \\
\hline Objective & \\
\hline Methodological approach & \\
\hline Main findings & \\
\hline Limitations & \\
\hline Indications for future studies & \\
\hline
\end{tabular}

Source: Research data (2020).

During the paper's integral reading, it was identified that new papers that were not obtained during the initial search would need to be introduced. This understanding came as recurring citations were being observed in different papers. The snowballing technique was applied as a way of systematizing this process (Ferrari et al., 2017; Kitchechan \& Brereton, 2013). It is understood that 
the combination of this technique with searches that utilize strings allows the researcher to obtain superior results (Petersen, Feldt, Mujtaba \& Mattsson, 2008).

In the case of this research, the "forward snowballing" was utilized because it is a way of obtaining new papers based on studies that are already considered relevant (Wohlin, 2014). In addition, a secondary approach was adopted, which means that the technique was applied on primary papers obtained by strings in automatic searches (Ferrari et al., 2017).

Literature shows that the inadequate use of this technique may induce bias and that a way through this issue is the careful evaluation of the studies before their inclusion in the review (Ferrari et al., 2017; Wohlin, 2014). Because of that, all papers found by snowballing were also analyzed as in the quality criteria form Table 3 . The method remained the same, as those that obtained a score equal or higher than 3 were included in the sample and had their data extracted as in Table 5. This process resulted in the addition of 11 papers, in the way presented on Table 6 , so that 20 papers composed the systematized analysis.

Table 6 - Papers inserted into the database after the snowballing and the qualification criteria

\begin{tabular}{|c|l|c|}
\hline Number & \multicolumn{1}{|c|}{ Paper title } & $\begin{array}{c}\text { Average } \\
\text { score }\end{array}$ \\
\hline $\mathbf{1 0}$ & What is project business? & 4,25 \\
\hline $\mathbf{1 1}$ & $\begin{array}{l}\text { A new framework for understanding organizational project management through } \\
\text { the pmo }\end{array}$ & 3,875 \\
\hline $\mathbf{1 2}$ & $\begin{array}{l}\text { Uncovering the trends in project management: journal emphases over the last } 10 \\
\text { years }\end{array}$ & 4,5 \\
\hline $\mathbf{1 3}$ & $\begin{array}{l}\text { Successful management of strategic intentions through multiple projects - } \\
\text { reflections from empirical study. }\end{array}$ & 5 \\
\hline $\mathbf{1 4}$ & $\begin{array}{l}\text { The project-based organization: an ideal form for managing } \\
\text { complex products and systems? }\end{array}$ & 4,75 \\
\hline $\mathbf{1 5}$ & Program management: a critical review & 4,25 \\
\hline $\mathbf{1 6}$ & Moving from corporate strategy to project strategy & 3,75 \\
\hline $\mathbf{1 7}$ & A Balanced Scorecard Approach to Project Management Leadership & 4,25 \\
\hline $\mathbf{1 9}$ & A two-way influence between business strategy and project management & 4,25 \\
\hline $\mathbf{2 0}$ & A theoretical framework for aligning project management with business strategy & 4,5 \\
\hline
\end{tabular}

Source: Research data (2020).

\section{Characterization of the data analysis}

The data analysis process was made in three sequential steps. At first, after surveying and tabulating the papers, their synthesis took place. In this stage, descriptive and exploratory analysis were performed, following the orientations of Kitchenhan and Charters (2007). For that, the journals and their impact factors were observed, as were the authors, citation numbers, methodological approach, abstracts, keywords and titles. For those tasks, the softwares VOSviewer (v.1.6.14), Biblioshiny and MS Excel (v.16.35). 
At second, the 20 resulting papers were integrally read in order to seek answers to the research question. From this, the contributions of the papers were analyzed and those that presented content that was directly related to research objectives were highlighted and concatenated to build the understanding that allowed answering the purpose of this research.

In the third moment, the findings of the papers were again analyzed. In this stage, elements were searched that, according to the authors, contribute to strategic alignment in project-based businesses. From those findings were made proposals that summarize and systematize the knowledge verified in the papers, as to explain, in the form of affirmations, knowledge that relates to the phenomenon (Köche, 2014). In order to build the propositions, the themes defined in Table 9 were considered.

\section{Results and discussion}

The application of the systematized review, as observed in the methodology, resulted in 20 papers presented in seven different journals, all in the field of Business and Administration, as seen in Table 7.

Table 7 - Characterization of the papers used in the SRL by journal

\begin{tabular}{|c|l|c|c|}
\hline \multicolumn{1}{|c|}{ Field } & \multicolumn{1}{|c|}{ Journal } & $\begin{array}{c}\text { Impact factor } \\
\text { (JCR) }\end{array}$ & $\begin{array}{c}\text { Number of } \\
\text { papers }\end{array}$ \\
\hline \multirow{4}{*}{$\begin{array}{c}\text { Business and } \\
\text { Administration }\end{array}$} & International Journal of Project Management & 4,694 & 10 \\
\cline { 2 - 4 } & Project Management Journal & 2,043 & 4 \\
\cline { 2 - 4 } & Advances in Strategic Management & 0,745 & 2 \\
\cline { 2 - 4 } & Research Policy & 5,425 & 1 \\
\cline { 2 - 4 } & Journal of management in Engineering & 3,269 & 1 \\
\cline { 2 - 4 } & International Journal of Managing Projects in Business & 1,6 & 1 \\
\cline { 2 - 4 } & Benchmarking: An International Journal & 1,04 & 1 \\
\hline
\end{tabular}

Source: Research data (2020).

The papers were all published between 2000 and 2019. Figure 3 shows the distribution of publishing of the papers throughout time. The time interval is presented in the $\mathrm{X}$-axis, and each item plotted in the graph represents a paper as the number established on Table 4 and 6, presented at the methodology. 
Figure 3 - Publishing distribution throughout time

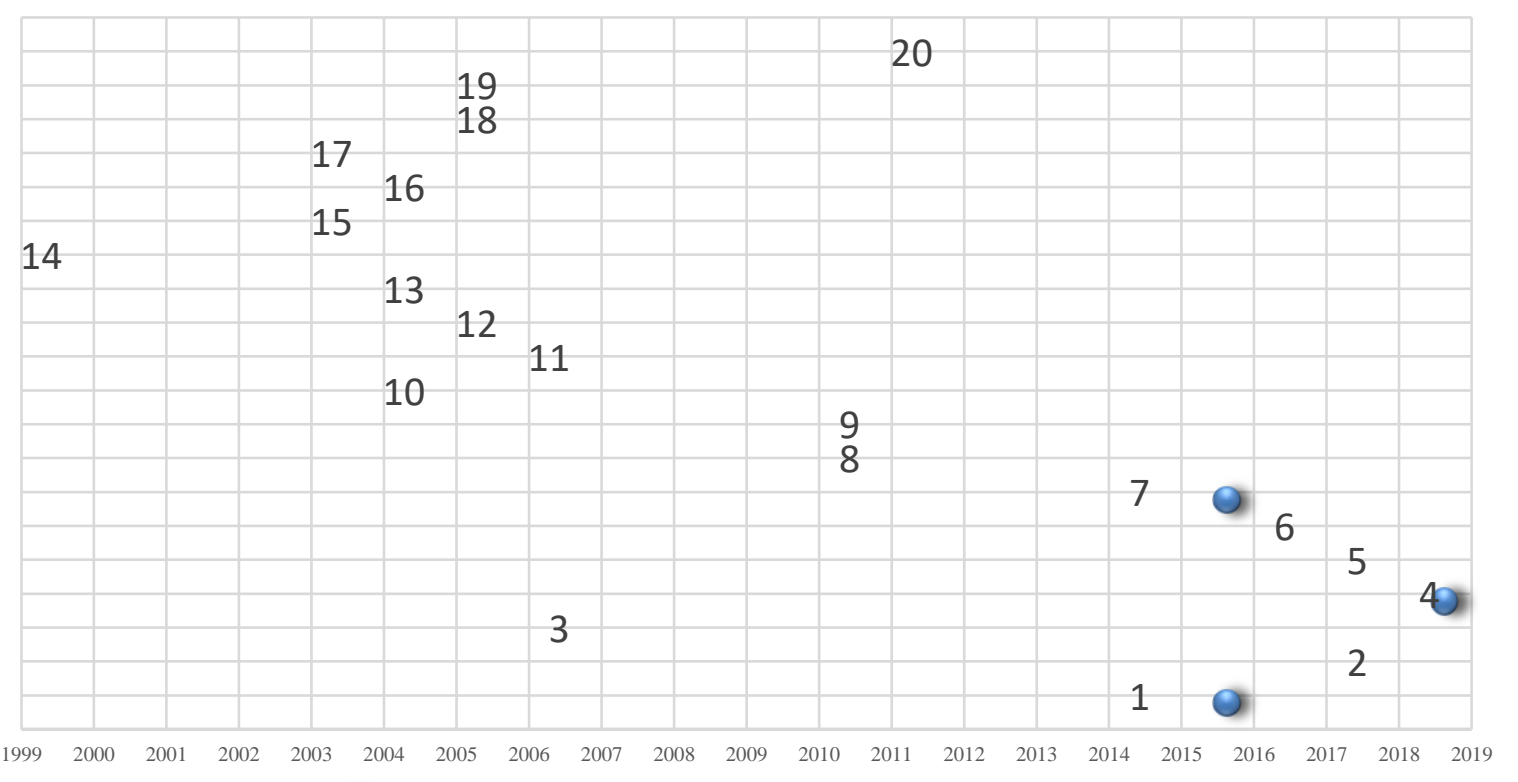

Source: Research data (2020).

It is noticed in Figure 3 that two periods concentrate most publications focusing on the approached topic: the period between 2004 and 2007 (ten publications), and the one between 2015 and 2019 (six publications). The publications contained in the first basically refer to the author's effort in relating organizational strategy and project management. In the second, it is realized that the knowledge produced in the first period finds itself sedimented, and the effort went to the improvement of those relationships, as to widen and diversify the comprehension over the related topics and with applications in different kinds of organizations.

Observing the publications that make up this paper`s corpus, it was sought to identify the methodological characteristics that focused on the approach adopted by the authors. Table 8 quantifies and synthetizes brought up information. The data extraction cards used in the systematized review can be found at https://bit.ly/rsl1 cards. Each work has its methodological approach specified in those cards.

Table 8 - Quantification of the methodological approaches

\begin{tabular}{|l|c|}
\hline \multicolumn{1}{|c|}{ Approach } & Number of papers \\
\hline Quantitative & 4 \\
\hline Qualitative & 9 \\
\hline Literature review & 7 \\
\hline & $\mathbf{2 0}$ \\
\hline
\end{tabular}

Source: Research data (2020).

From analyzing those papers, it was found a prominence of both the qualitative and literature review approaches. Such aspect lies at the fact that papers normally point to either studies that seek to comprehend the behavior of certain organizations in the light of theoretical constructs and methods of result analysis, or the construction of frameworks that explain different organizational realities. Papers 
that opted for the quantitative approach can also be characterized as case studies, specific or multiple, based on applying statistical models aiming to quantify impacts or generalizing premises over certain phenomena.

Observing the contents from the papers, it was sought to comprehend the main topics discussed by the papers, and to identify parallels between publications.

It is important to highlight that is not clear in most analyzed papers the prominence or identification of theories basing the construction of the arguments. What can be generally seen are theoretical constructs and the application of bibliographical reviews in order to justify their own results in the bulk of the discussion found in literature.

This way, from the analysis of the abstract and title of the papers, the terms most addressed by the authors were identified and it was yet sought to identify the co-occurrences of fundamental terms. Using the software VOSviewer, Figure 4 was built, which presents the main highlighted terms, as well as their relationships and co-occurrences.

Figure 4 - Map of keyword co-occurrence

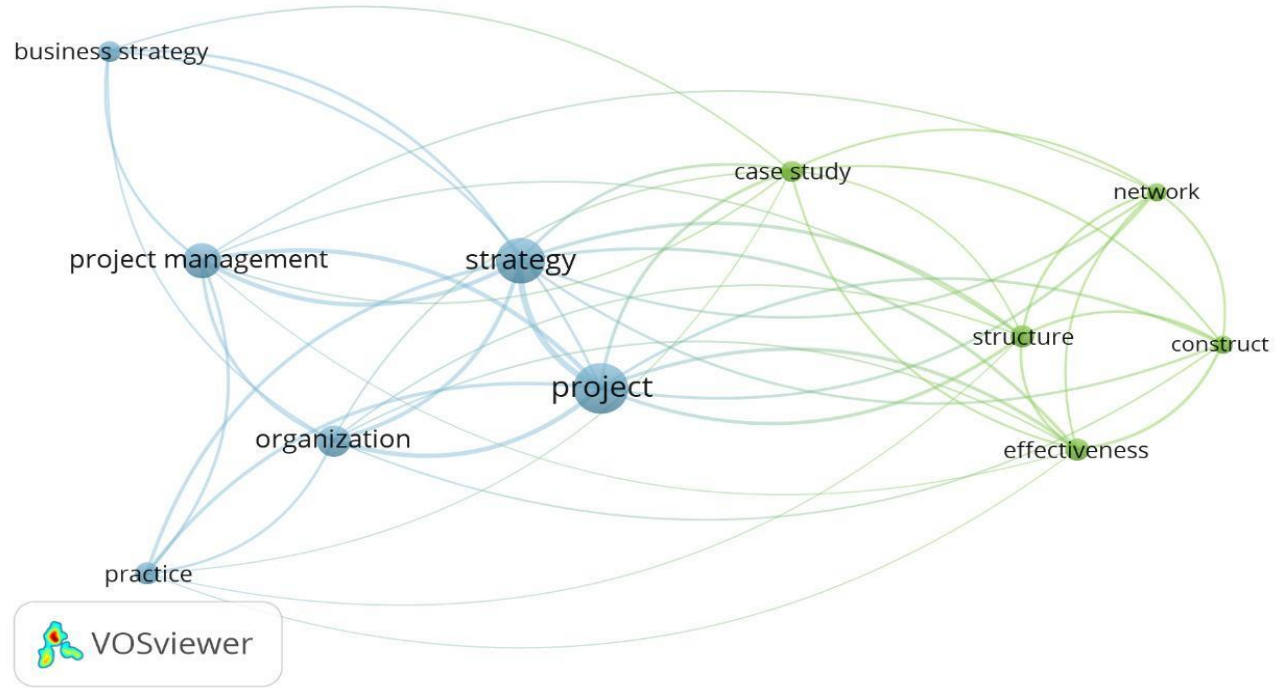

Source: Research data (2020).

It is noticeable the centrality of the terms "strategy" and "project" and their interaction with others observed. The colors show the clustering of the words with more co-occurrences among themselves. The links present the interactions between the concepts. It is seen that, in fact, the highlights correspond to what is sought to show, being the relationship between strategy and project management.

Besides, with the help of the software Biblioshiny a word cloud was built considering the elaboration criteria of the co-occurrences map. Figure 5 is the obtained output. 
Figure 5 - Word cloud from the abstracts of the publications

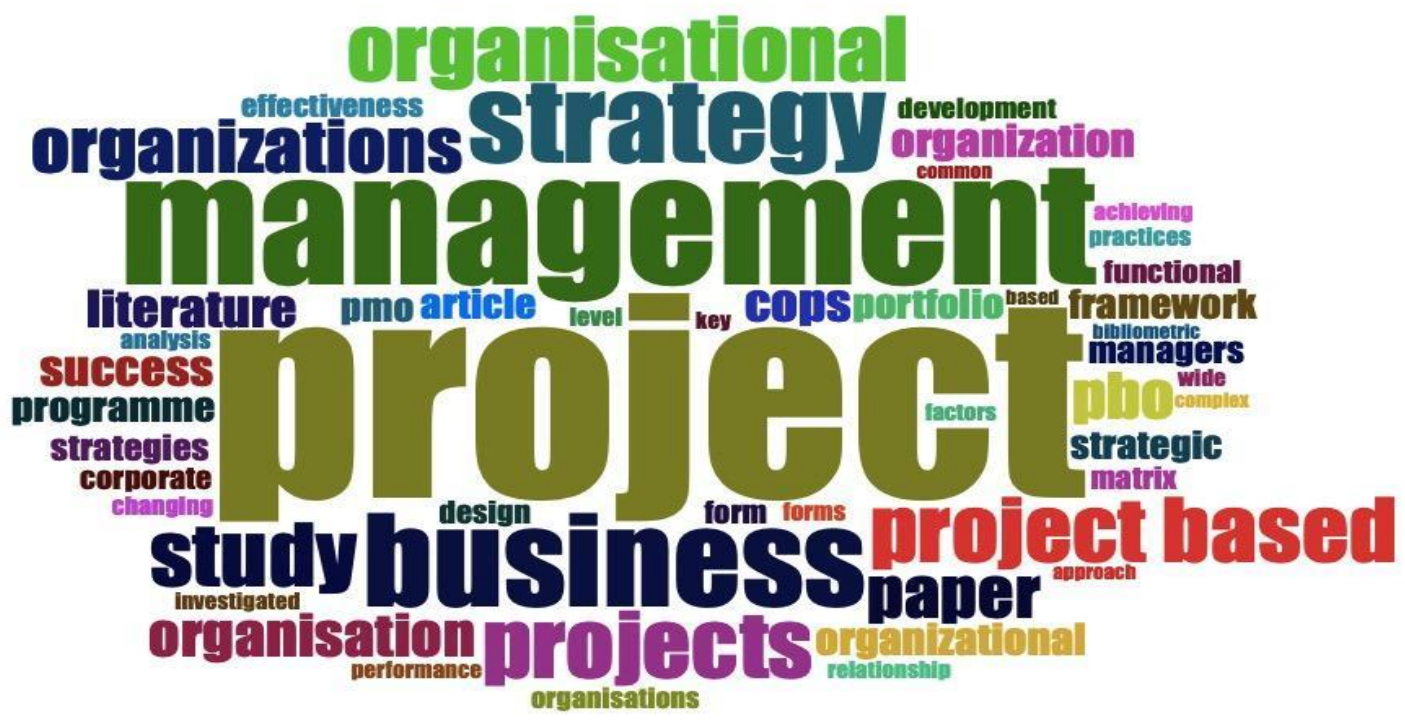

Source: Research data (2020).

The size of the words correlates to their frequency in the analyzed studies. This figure differs from the co-occurrences map because it presents the frequency of words while the Map demonstrates the joint relationships between the terms. Here again the keywords to the study are presented as those with the higher frequency, once again indicating that utilized database can offer important aspects to the analysis discussed by this paper.

Still analyzing the articles that set the sample, it appears that Hobday's (2000) has the highest number of citations: 1699, it is understood that this is because it is the oldest and also to have been published in the journal greater impact on the sample $(\mathrm{JCR}=5,425)$. The theme addressed in the study is transversal and fundamentally covers the characteristics of PBBs, their application, and the analysis of the efficiency and effectiveness of their functions, being the basis for a significant amount of work in the field. Besides, this article is also the most cited within the analyzed sample.

Exploring the references of the articles in the sample, there is a low amount of co-citations, which means that the works found are little cited by others who also compose the sample. From this, it appears that the project management area does not have a significant theoretical foundation, which creates a situation of little connection between the authors, so that each one, in his way, makes considerations and establishes some peculiarities about the concepts addressed. These inferences confirm the understanding that the project management literature lacks valid and consistent theoretical foundations and empirical models (Aubry, Hobbs \& Thuillier, 2007).

When dealing with the specific issues of the papers that compose the corpus of the analysis, Table 9 presents a synthesis of that information. The construction of this framework considered the reading of the introductions and final considerations of the papers as to identify the objectives and the findings of each investigation. Four research topics were identified, properly categorized in the table. 
Table 9 - Topics discussed by authors

\begin{tabular}{|ll|l|}
\hline \multicolumn{2}{|c|}{ Research topics } & \multicolumn{1}{c|}{ Authors } \\
\hline $\begin{array}{l}\text { 1. Project management } \\
\text { organizational strategy in PBB }\end{array}$ & $\begin{array}{l}\text { Ansari } \text { et al. (2015); Sandhu, Al Ameri and Wikström (2018); } \\
\text { Cattani, Ferriani, Frederiksen and Täube (2011); Artto and } \\
\text { Wikström (2005); Dietrich and Lehtonen (2005); Hobday } \\
\text { (2000); Morris, and Jamieson (2005); Milosevic and } \\
\text { Srivannaboon (2006); Srivannaboon and Milosevic (2006); } \\
\text { Young, Young, Jordan and O'Connor (2012). }\end{array}$ \\
\hline $\begin{array}{l}\text { 2. Integration between actors in } \\
\text { project-based organizations }\end{array}$ & $\begin{array}{l}\text { Löwstedt, Räisänen and Leiringer (2018); Lampel (2011); } \\
\text { Norrie and Walker (2004). }\end{array}$ \\
\hline $\begin{array}{l}\text { Program management, portfolio and } \\
\text { management }\end{array}$ & $\begin{array}{l}\text { Thiry and Deguire (2007); Petro and Gardiner (2015); Lycett, } \\
\text { Rassau and Danson (2004). }\end{array}$ \\
\hline $\begin{array}{l}\text { 4. Project management office and } \\
\text { design of the PBB }\end{array}$ & $\begin{array}{l}\text { Turner and Miterev (2019); Miterev, Turner and Mancini } \\
\text { (2017); Aubry } \text { et al. (2007); Crawford, Pollack and England } \\
\text { (2006). }\end{array}$ \\
\hline
\end{tabular}

Source: Research data (2020).

Topic 1 (Project management and organizational strategy in PBB) presents the larger amount of papers in the sample, amounting to $50 \%$ of the observed studies. The main trait of this topic is to deal with various dynamics and analyses on the aspects of project management and its relationships with the perspective of the strategy inside a PBB, which provides a very diverse comprehension on the topic.

On topic 2, it is worth to highlight in the papers that compose an effort in demonstrating the project management role under the perspective of the involved actors, indicating that they are important not just to the implementation of the projects, but also to the adjustment of the strategies so that those can become properly aligned projects.

Analyzing topic 3 papers, it is emphasized that they present adhering topics to the research objective; important to understanding the dynamic, but that do not completely approach the main focus of the investigation. Finally, the aspects seen in topic 4 involve tools and project management structures (design) applied to the PBB. This topic shows to be more important to the research as it is believed that the adequate use of those organizational structures and tools make the strategic alignment more efficient by the means of projects.

This way, considering all issues addressed with regard to the characteristics of the papers that make up the corpus; the qualified information in the discussed topics and issues; and even the relationship between the publications and the observed gaps, especially in regard to theoretical weaknesses, we arrive at the consolidation of the addressed content in order to answer the research question as to the role of project management in the alignment of the organizational strategy.

\section{Strategic alignment in a Project-based business}

Strategic alignment is recognized as one of the most notable topics present at the Journal of Project Management and International Journal of Project Management (Crawford et al., 2006). Analyzing the corpus of this research, it is seen that in most papers this issue is brought up directly or 
indirectly. Therefore, it is understood that the unfolding process of the organizational strategy by means of projects necessarily goes through the option for an approach that aligns strategy to projects.

In this perspective, Srivannaboon and Milosevic (2006) dedicated themselves to building a theoretical structure that approaches two main issues: the reciprocal influence between project management, organizational strategy and the process used to align both aspects. This structure highlights the relevance of the alignment between project management and the organizational strategies. To the authors, different business strategies require different elements and focuses from project management. Therefore, it is important that the organizations carry out their business strategies and identify appropriate project management configurations that correspond to the strategies (Srivannaboon \& Milosevic, 2006).

To Ansari et al. (2015), the alignment between strategy and project management helps organizations to focus themselves appropriately in the projects and reach the strategic goals of the business. According to the authors, one of the greatest challenges of the organizations is developing a method of conversion from business strategies in project strategies. Therefore, they propose a framework (Figure 6) to help in the process:

Figure 6 - Framework for the alignment of project management to the organizational strategies

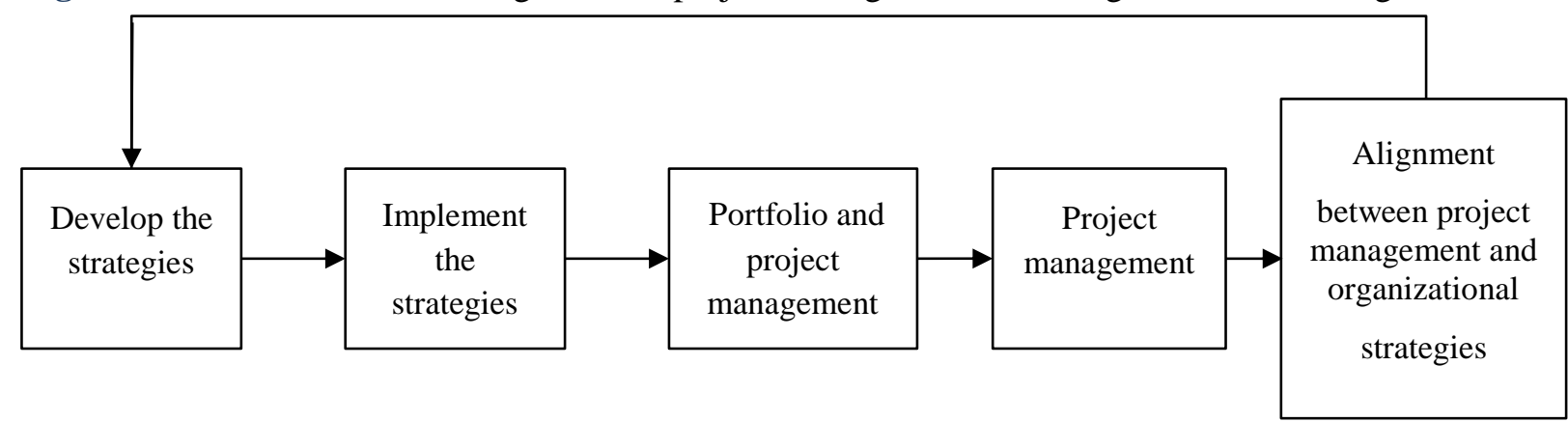

Source: Own elaboration based on Ansari et al. (2015).

In that sense, the study developed by Young et al. (2012) ratifies the need for aligning the projects carried out in the organizational sphere to the strategy. The findings show that occurring failures in the way projects are managed and selected can make them not contribute meaningfully with the achievement of the strategy. Besides, there is a suggestion that the field of program management, when not properly executed, can be the responsible for those failures.

The program management can be comprehended as the link between project management and organizational strategy. In the work made by Lycett et al. (2004), the authors punctuated some issues that can cause this activity not to be carried out optimally, such as excessive control; little flexibility on the strategy development; and ineffective cooperation between the projects included in the program. The results of this investigation demonstrate that those problems may be due to two misguided suppositions about program management: (1) that it is an expanded version of the project management; and (2) that the application of a standard approach is appropriate to all organizations. 
Another topic related to program management and addressed in literature as competent to make the alignment is the portfolio management. Morris and Jamieson (2005) pointed to these activities as one of the critical steps concerning the alignment. To the researchers, this activity can be responsible for moving the strategy from the corporate level to the project execution level. The results of the investigation made by the authors show that the portfolio management is made by many organizations. Yet, in most of them, it is seen only as managing projects with analog topics and not as a means of keeping a balanced portfolio of projects or selecting the right projects.

Another relevant element is the role of project managers. Söderlund and Maylor (2012) argue that a way of integrating strategy and its execution to project management is getting involved with the people responsible for the strategy and with the project managers, as to know the limits and differences in their perspectives before the realization of the strategy. However, in recent research developed by Löwstedt et al. (2018) there is a contradiction to this paradigm, as the author's discoveries point to an overlap of roles and practices, that is, project managers acting in their main function and as legit organizational strategists.

In that perspective, Thiry and Deguire (2007) defends that this collaborative relationship between senior management and project execution sectors deserves attention, especially concerning the development of a common language between these organizational areas. In addition, the author's findings also highlight the need to recognize that the project management influences and is influenced by the organizational practices.

An interesting point of this study is the reconishment that, in the case of the PBB, it is necessary to widen the strategy's perspective and adopt organizational models appropriated to those structures. The analysis shows that the organizations adopting this functional model have some difficulties when implanted in traditional structures, such as coordinating the learning and development of the organization; linking projects to organizational processes; grouping the interests of different stakeholders and getting the acceptance of the different traditional functional units.

In the context of PBB, the paper of Löwstedt et al. (2018) is again brought up to deepen understanding about the alignment process of the organizational strategy by project management. The research developed by the authors has shown the need to surpass the conception that the projects are mere places for the implementation of the strategy. In their understanding, the projects shape the organizational strategies, even influencing the strategic direction taken by the managers.

According to literature, it is possible to identify two general aspects about the alignment between strategy and projects. Part of the authors defend practices and orientations over how this alignment should occur, establishing a method or emphasizing the need for collaboration and interdependence between senior management and the definition/execution of projects.

Another group of authors highlights the roles exerted by program management, portfolio management and project managers as relevant topics for alignment and consequently the unfolding to occur. In this sense, it is worth to emphasize the lack of other roles, like PMO or even project 
management technique adopted. These organizational elements are recognized as important to project governance (Too \& Weaver, 2014) and should be further explored as to their contributions to the alignment between strategy and projects.

Finally, considering project-based organizations, it is fundamental to comprehend that this organizational model requires, in first place, the understanding that, in these conjunctures, projects have a relevant role, been influenced not only by the strategies, but also influencing them, which requires increasingly flexible, collaborative and adjusted structures (Löwstedt et al., 2018; Thiry \& Deguire, 2007).

This way, it is inferred that most existing problems on the alignment of the organizational strategy involve the inadequate or inconsistent use of project management practices. Thus the main orientation to the PBB in what concerns the alignment of the strategy is making practices suitable to the organizational structures, in the sense that they should be used to respond the demands of the organization, and should not be adopted in an inflexible way, but according to the objectives and available resources in each organization.

Besides, over the last years studies point that mature PBBs should prioritize the adoption of integrative approaches that allow conscient structures, strategy delivery and knowledge standardization (Thiry \& Deguire, 2007). In this sense, it is seen that the adoption of organizational elements relevant to project management as project management offices, program/portfolio management routines, or project governance models, can enhance the effectuation of the alignment of the strategy in organizations of this nature.

\section{Propositions over strategic alignment in project-based businesses}

As a result of this review, a series of elements was verified that, according to the literature, exert influence over the strategic alignment process considering PBBs, and that certain scenarios may strengthen the strategic alignment by projects.

Based on this, as a way to synthesize these findings, it was sought to systematize the result of the research from elaborating the proposals that emerged from the analyses. The intent was to group and contextualize the findings through affirmation that may be observed in other studies, so that it can be verified if these elements influence the strategic alignment not only in isolated form, but also in conjunction with other elements.

The idea was to elucidate ways for the formation of a research agenda that can guide investigations related to the strategic alignment in project-based businesses. The proposals were elaborated to provide an initial perspective over the topic, in a way that the delimitation process of the problem as well as the research definition be facilitated. Besides, they were originally built and grouped based on the topics established in Table 10, so that researchers interested in the discussed issues can consult the papers referenced in each one of them as an initial source for their research. 
Table 10 - Set of propositions over strategic alignment in PBB

\begin{tabular}{|c|c|}
\hline Research topics & Propositions \\
\hline \multirow{3}{*}{$\begin{array}{l}\text { 1. Project management and } \\
\text { organizational strategy in } \\
\text { PBB }\end{array}$} & $\begin{array}{l}\text { 1. Simple and flexible project management methodologies serve as } \\
\text { instruments in the implementation of organizational strategies by projects. }\end{array}$ \\
\hline & 2. It is made clear the contribution of each individual project to the strategy. \\
\hline & $\begin{array}{l}\text { 3. The projects developed by the organization as the primary responsible for } \\
\text { the achievement of the organizational objectives. }\end{array}$ \\
\hline \multirow{3}{*}{$\begin{array}{l}\text { 2. Interactions between } \\
\text { actors in the formation of } \\
\text { strategies in project-based } \\
\text { organizations }\end{array}$} & $\begin{array}{l}\text { 4. The project managers also act like organizational strategists, being aware } \\
\text { of the project's contributions to reaching the organizational objectives. }\end{array}$ \\
\hline & $\begin{array}{l}\text { 5. Senior management understands that project management can influence } \\
\text { organizational strategies. }\end{array}$ \\
\hline & $\begin{array}{l}\text { 6. The project managers create a positive interaction between the strategic } \\
\text { processes. }\end{array}$ \\
\hline \multirow{3}{*}{$\begin{array}{l}\text { 3. Management of programs, } \\
\text { portfolio and governance. }\end{array}$} & $\begin{array}{l}\text { 7. The organization understands the conceptual differences between } \\
\text { program management, portfolio management and project management. }\end{array}$ \\
\hline & $\begin{array}{l}\text { 8. The organization adopts its own protocol for selection and prioritization } \\
\text { of projects focusing on reaching strategic objectives. }\end{array}$ \\
\hline & $\begin{array}{l}\text { 9. There are specific and distinct methodologies to program, portfolio and } \\
\text { project management. }\end{array}$ \\
\hline \multirow{3}{*}{$\begin{array}{l}\text { 4. Project management } \\
\text { office and PBB design. }\end{array}$} & 10. The project management office supports the achievement of the strategy. \\
\hline & $\begin{array}{l}\text { 11. The project management office promotes the development of the best } \\
\text { ecosystem of strategy achievement. }\end{array}$ \\
\hline & 12. The project management office links strategy to projects. \\
\hline
\end{tabular}

Source: Research data (2020).

These propositions can provide a reference base to be investigated concerning strategic alignment. Thus, it will be possible to verify if the paper's findings, observed in the literature review, are configured in practice. It is stimulated that studies are made to deepen the knowledge over these topics with the intention that the field of research on project management is strengthened and that there is a validation of the assumptions achieved in the studies, given that the scientific literature on the topic still lacks basing and validation (Aubry et al., 2007).

\section{Final considerations}

This research intended to understand the theoretical-empirical connections of strategic alignment in project-based businesses. For that, a systematized literature review was conducted, as this method constitutes an appropriate approach for the resolutions of scientific questions from already conducted studies.

The results showed the existence of a mutual influence between the strategic alignment and project management. It was identified that the alignment helps organizations to focus their efforts in timely projects, while project management helps them to reach their strategic goals. The flaws in this relationship are attributed to two points: the adoption of GP elements or practices inadequate to the organizational structures or their use in a misguided way. As enhancers of effectiveness of this cycle, the following GP elements were observed: program management, portfolio management and project 
managers. In the PBB sphere, this whole conjuncture is accentuated, which requires a level of adequacy and understanding of the practices GP elements even more elevated.

Beyond identifying literature contributions, the study advanced in the topic's debate, systematizing the findings and building a set of propositions that resumes the main ideas that emerged from the papers. It is understood that this proposition set elucidates ways for the formation of a research agenda capable of guiding and facilitating the development of other investigations.

Besides, the literature review also highlighted the need for the collaboration of papers with a deeper theoretical background that can serve to develop the research field. That is, as seen in topic 2, there is no standard of either the concepts or theoretical constructs used by the authors, which makes it difficult to understand and may create misguided interpretations. Thus, it is understood that the theoretical-empirical connections made about strategic alignment in the context of PBBs constitute a significant contribution for researchers who are dedicated to the study of PBBs because until then there were no scientific studies that focused specifically on this business model.

This research had two priority limitations: the limited number of researchers to verify the results obtained in the databases and the non-standardization of the concepts, which made automatic research harder.

For future research are suggested investigations that deepen the points approached in topic 4.3, as for example: papers on the role of program management, portfolio management, the process of implementation of the organizational strategies, functions exerted by the project managers in regard to strategy, paradigm changes in the role of projects in project-based organizations. Overall, observing the corpus of the research, it is recommended the execution of empirical and quantitative research over the topics discussed in this study.

The managerial implications are many, from the understanding that project managers must extrapolate their basic functions and start to act in line with senior management, acting in some cases as strategists, until the understanding of the need to adapt organizational structures to projects in a way that allows for mutual influence between projects and strategies. Also, this knowledge can help decision-makers to identify more efficient ways to implement the strategy.

This research contributes to the literature as it synthesizes the main studies that approach the topic, identifies scientific gaps to be explored in future studies and makes an overview of the bibliography over the relationship between project management and the alignment of organizational strategy within project-based organizations.

Finally, it is understood that the effort spent for the resolution of the research question was successful, that the proposed goal was reached and that this investigation has relevance both of practical nature, considering that it made several inferences that may be used by managers, and of scientific nature, seeing its contribution to the growth of the research on project management and the rigor in which it was executed. 


\section{References}

Ansari, R., Shakeri, E., \& Raddadi, A. (2015). Framework for aligning project management with organizational strategies. Journal of Management in Engineering, 31(4), 04014050, 1-8. https://doi.org/10.1061/(ASCE)ME.1943-5479.0000249.

Anselmo, J. L. (2009). Gerenciamento de projetos em negócios baseados em projetos: uma proposta integrada das dimensões operacional, organizacional e estratégica. Tese de doutorado, Universidade de São Paulo, São Paulo, SP, Brasil. Available in: https://teses.usp.br/teses/disponiveis/12/12139/tde-29012010-160441/pt-br.php.

Archibald, R. D. (2005, october 19). State of the Art of Project Management: 2005-2010. Keynote presentation to the PMI Milwakee/Southeast Wisconsin Chapter, Professional Development Day. Recovered in mar, 2020, de http://russarchibald.com/recent-papers-presentations/state-of-theart/state-art-pm-in-2010-milwaukee/.

Artto, K. A., \& Wikström, K. (2005). What is project business? International Journal of Project Management, 23(5), 343-353. https://doi.org/10.1016/j.ijproman.2005.03.005.

Aubry, M., Hobbs, B., \& Thuillier, D. (2007). A new framework for understanding organisational project management through the PMO. International journal of project management, 25(4), 328336. https://doi.org/10.1016/j.ijproman.2007.01.004.

Burrel, G. \& Morgan, G. (1979). Sociological Paradigms and Organizational Analysis. Heineman: London.

Cattani, G., Ferriani, S., Frederiksen, L., \& Täube, F. (2011). Project-based organizing and strategic management: A long-term research agenda on temporary organizational forms. Advances in Strategic Management, 28, 3-26. https://doi.org/10.1108/S0742-3322(2011)0000028004.

Costa, A. B., \& Zoltowski, A. P. C. (2014). Como escrever um artigo de revisão sistemática. In Koller, S. H., Couto, M. C. P. de., \& Hohendorff, J. Von. (2014). Manual de produção científica. Porto Alegre: Penso.

Crawford, L., Pollack, J., \& England, D. (2006). Uncovering the trends in project management: Journal emphases over the last 10 years. International journal of project management, 24(2), 175184. https://doi.org/10.1016/j.ijproman.2005.10.005.

Dieste, O., Grimán, A., \& Juristo, N. (2009). Developing search strategies for detecting relevant experiments. Empirical Software Engineering, 14(5), 513-539.

https://doi.org/10.1109/ESEM.2007.19.

Dietrich, P., \& Lehtonen, P. (2005). Successful management of strategic intentions through multiple projects-Reflections from empirical study. International Journal of Project Management, 23(5), 386-391. https://doi.org/10.1016/j.ijproman.2005.03.002.

Dybå, T., \& Dingsøyr, T. (2008). Empirical studies of agile software development: A systematic review. Information and Software Technology, 50(9-10), 833-859.

https://doi.org/10.1016/j.infsof.2008.01.006.

Englund, R. L., \& Graham, R. J. (1999). From experience: Linking projects to strategy.” Journal Product Innovation Management 16(1), 52-64. 
Felizardo, K. R., Souza, E. F., \& Falbo, R. A. (2017). Seleção e avaliação de estudos. In K. R. Felizardo, E. Y. Nakagawa, S. C. P. F. Fabbri, \& F. C. Ferrarri (Eds.), Revisão sistemática da literatura em engenharia de software. Rio de Janeiro: Elsevier.

Ferrari, F. C., Oliveira, L. R. de, Siqueira, B. R., \& Silva, C. R. Q. (2017). In K. R. Felizardo, E. Y. Nakagawa, S. C. P. F. Fabbri, \& F. C. Ferrarri (Eds.), Revisão sistemática da literatura em engenharia de software. Rio de Janeiro: Elsevier.

Fisch, C., \& Block, J. (2018). Six tips for your (systematic) literature review in business and management research. Management Review Quarterly, 68(2), 103-106. https://doi.org/10.1007/s11301-018-0142-x.

Frank H., \& Hatak. I. (2014). Doing a research literature review. In: Fayolle A, Wright M (eds) How to get published in the best entrepreneurship journals. Edward Elgar, Cheltenham, 94-117.

Grant, M. J., \& Booth, A. (2009). A typology of reviews: an analysis of 14 review types and associated methodologies. Health Information \& Libraries Journal, 26(2), 91-108. https://doi.org/110.1111/j.1471-1842.2009.00848.x.

Hobday, M. (2000). The project-based organisation: an ideal form for managing complex products and systems? Research policy, 29(7-8), 871-893. https://doi.org/10.1016/S0048-7333(00)00110-4.

Huemann, M., \& Stummer, M. (2000, May). Benchmarking the pm-competence of project-oriented organisations. IPMA World Conference, Londres, UK.

Kenny, J. (2006). Strategy and the learning organization: A maturity model for the formation of strategy. The Learning Organization, 13(4), 353-368. https://doi.org/10.1108/09696470610667733.

Kitchenham, B., \& Brereton, P. (2013). A systematic review of systematic review process research in software engineering. Information and software technology, 55(12), 2049-2075. https://doi.org/10.1016/j.infsof.2013.07.010.

Kitchenham, B., \& Charters, S. (2007). Guidelines for performing Systematic Literature reviews in Software Engineering Version 2.3. Engineering, 45(4ve), 1051.

Köche, J. C. (2014). Fundamentos de metodologia científica (34a ed). Petrópolis: Editora Vozes.

Kwak, Y.H., \& Anbari, F.T. (2009). Analyzing project management research: perspectives from top management journals. International Journal of Project Management, 27, 435-446. https://doi.org/10.1016/j.ijproman.2008.08.004.

Lampel, J. (2011). Institutional dynamics of project-based creative organizations: Irving Thalberg and the Hollywood studio system. Advances in strategic management, 28, 445-466. https://doi.org/10.1108/S0742-3322(2011)0000028020.

Löwstedt, M., Räisänen, C., \& Leiringer, R. (2018). Doing strategy in project-based organizations: Actors and patterns of action. International Journal of Project Management, 36(6), 889-898. https://doi.org/10.1016/j.ijproman.2018.05.002.

Lycett, M., Rassau, A., \& Danson, J. (2004). Programme management: a critical review. International Journal of Project Management, 22(4), 289-299. https://doi.org/10.1016/j.ijproman.2003.06.001. 
Milosevic, D. Z., \& Srivannaboon, S. (2006). A theoretical framework for aligning project management with business strategy. Project Management Journal, 37(3), 98-110. https://doi.org/10.1177/875697280603700310.

Miterev, M., Turner, J. R., \& Mancini, M. (2017). The organization design perspective on the project-based organization: a structured review. International Journal of Managing Projects in Business, 10(3), 527-549. https://doi.org/10.1108/IJMPB-06-2016-0048.

Morris, P. W., \& Jamieson, A. (2005). Moving from corporate strategy to project strategy. Project Management Journal, 36(4), 5-18. https://doi.org/10.1177/875697280503600402.

Norrie, J., \& Walker, D. H. (2004). A balanced scorecard approach to project management leadership. Project management journal, 35(4), 47-56. https://doi.org/10.1177/875697280403500406.

Petro, Y., \& Gardiner, P. (2015). An investigation of the influence of organizational design on project portfolio success, effectiveness and business efficiency for project-based organizations. International Journal of Project Management, 33(8), 1717-1729. https://doi.org/10.1016/j.ijproman.2015.08.004.

Petersen, K., Feldt, R., Mujtaba, S., \& Mattsson, M. (2008). Systematic mapping studies in software engineering. In 12th International Conference on Evaluation and Assessment in Software Engineering (EASE), Swindon, United Kingdom, 12.

Project Management Institute (PMI). (2017). A guide to the project management body of knowledge - PMBok (6. ed.). Pennsylvania: Project Management Institute.

Raps, A. (2005). Strategy implementation: an insurmountable obstacle? Handbook of Business Strategy, 6(1), 141-146. https://doi.org/10.1108/08944310510557152.

Sandhu, M. A., Al Ameri, T. Z., \& Wikström, K. (2019). Benchmarking the strategic roles of the project management office (PMO) when developing business ecosystems. Benchmarking: An International Journal, 26(2), 452-469. https://doi.org/10.1108/BIJ-03-2018-0058.

Schwarz, F., Amiden, M. A. M., \& Pinho, L. C. (2005). Alinhamento e desdobramento da estratégia. In Coutinho, A. R., Kallas, D. (Eds.), Gestão estratégica: experiências e lições de empresas brasileiras. Rio de Janeiro: Campus.

Shenhar, A. J., Milosevic, D., Dvir, D., \& Thamhain, H. (2007). Linking project management to business strategy, Philadelphia: PMI.

Snyder, H. (2019). Literature review as a research methodology: An overview and guidelines. Journal of Business Research,104, 333-339. https://doi.org/10.1016/j.jbusres.2019.07.039.

Söderlund, J., \& Maylor, H. (2012). Project management scholarship: Relevance, impact and five integrative challenges for business and management schools. International Journal of Project Management, 30(6), 686-696. https://doi.org/10.1016/j.ijproman.2012.03.007.

Sousa, M. V., Neto (2017). Project Based-Business. Rio de Janeiro: Brasport.

Srivannaboon, S., \& Milosevic, D. Z. (2006). A two-way influence between business strategy and project management. International journal of project management, 24(6), 493-505.

https://doi.org/10.1016/j.ijproman.2006.03.006. 
Srivannaboon, S., \& Milosevic, D. Z. (2004). The process of translating business strategy in project actions. Innovations Project Management Research. Newtown Square, PA: Project Management Institute.

Thiry, M., \& Deguire, M. (2007). Recent developments in project-based organisations. International journal of project management, 25(7), 649-658. https://doi.org/10.1016/j.ijproman.2007.02.001.

Too, E. G., \& Weaver, P. (2014). The management of project management: A conceptual framework for project governance. International Journal of Project Management, 32(8), 1382-1394. https://doi.org/10.1016/j.ijproman.2013.07.006.

Turner, R., \& Miterev, M. (2019). The organizational design of the project-based organization. Project Management Journal, 50(4), 487-498. https://doi.org/10.1177/8756972819859746.

Wohlin, C. (2014, May) Guidelines for snowballing in systematic literature studies and a replication in software engineering. International Conference on Evaluation and Assessment in Software Engineering (EASE 2014), Karlskrona, Sweden, 18. http://dx.doi.org/10.1145/2601248.2601268.

Young, R., \& Grant, J. (2015). Is strategy implemented by projects? Disturbing evidence in the State of NSW. International Journal of Project Management, 33(1), 15-28. https://doi.org/10.1016/j.ijproman.2014.03.010.

Young, R., Young, M., Jordan, E., \& O'Connor, P. (2012). Is strategy being implemented through projects? Contrary evidence from a leader in New Public Management. International Journal of Project Management, 30(8), 887-900. https://doi.org/10.1016/j.ijproman.2012.03.003. 